\title{
Why Low-Calorie Diets Might be Good for Your Brain in More Than One Way?
}

\author{
JZ Dalgaard* \\ Warwick Medical School, University of Warwick, UK
}

Submission: June 19, 2017; Published: July 10, 2017

*Corresponding author: JZ Dalgaard, Warwick Medical School, University of Warwick, CV47AL Coventry, UK, Tel: 004407939692966; Email: jzeuthendalgaard@gmaiil.com

\section{Mini Review}

The central nervous system is normally considered a tissue with low ability to regenerate, as in adult patients injuries to the central nervous system display a low capacity to heal and restore function. However, it might be that evolution has led to the establishment of a nutritional state mediated neural regeneration "program" that can be activated using diets to help the recovery in patients with nerve and brain damage. As the animals we are, the most important we do short-term is to eat. Without eating at regular intervals, we will loose weight, our health will deteriorate and we will in the end perish. Thus, one has to ask oneself, what would have happened through our evolutionary history, going all the way back to the first ancestral multi-cellular organisms that had a central nervous system, when there was an injury to the central nervous system; such injuries would all have led to a period of starvation or low-calorie intake. Thus, it is likely that a cellular nerve-regeneration program, if it exists, will be induced by starvation or reduced food intake. Indeed, it could, even in periods of low-calorie intake, without damage to the central nervous system, be beneficial to "invest" in improved central nervous system functions, as it is likely to lead to improved food-intake, especially if food is limiting.

Interestingly, studies on mice using calorie restriction diets have shown that such diets alleviate age-related decrease in neural progenitor cell division in aging individuals [1]. It is important to note that in these studies there were not detected more newly divided nerve-cells. However, here it is important, to note that these mice were given diets with reduced calories over longer periods. Thus, the diets were low-calorie diets, but not diets that would correspond to a starvation situation. Also, just the presence of neural progenitor cells suggests an improved ability to recover in the case of damage to the central nerve=system, showing that even such a diet have beneficial effects on brain functions.
Importantly, starvation or low-calorie diets might not only have a positive effect on nerve-regeneration, but also on the metabolic and functional states of the nerve-cells: Firstly, type-two diabetes has recently been proposed to be caused by cells protecting themselves against the damaging effects of inter-cellular high-glucose levels; or put a different manner type-two diabetes is due to silencing of genes involved in the uptake and metabolism of glucose [2]. Here it is important to note, that glucose is the main energy source of the nerve-cells; even more so than other tissues. Interestingly, diabetes has also been associated with a greater incidence of dementia, and one possibility is that in this tissue, silencing of genes involved in uptake and metabolism of glucose might be directly be related to the progression of dementia [3]. Importantly, several studies suggest that low-calorie diets can be employed to revert type II diabetes patients blood-sugar levels to normal $[4,5]$, potentially by resetting the transcriptional program of the genes involved in the uptake and metabolism of glucose [2]. Thus, in this connection, it is worth mentioning that in doing so these lowcalorie diets might also prevent the mental decline associated with diabetes.

Secondly, there is the issue of Alzheimer. Alzheimer is another type of dementia-causing disease that is due to the aggregation and accumulation of a phosphorylated version of a microtubule-associated protein called tau [6]. Here aggregation of tau might act like blood clothing to prevent loss of cytoplasm when axons on nerve-cells get sheered [7]. It is known that low-calorie diets also lead to intra-cellular auto-phagotization of proteins, and it is thus possible that these diets also might reduce the accumulation of aggregated tau and therefore the risk of Alzheimer.

Importantly, it should be noted that very low calorie diets are not without risks. Headaches, dizziness, inability to focus, 
loss of minerals (especially calcium), constipation, loss of muscle mass and gallstones have been observed during verylow-calorie diets. However, with these possible complications in mind it might be possibly to safely use very-low-calorie diets for prevention of type II diabetes and for the regeneration of nervecell function and numbers.

\section{References}

1. Park JH, Glass Z, Sayed K, Michurina TV, Lazutkin A, et al. (2013) Calorie restriction alleviates the age-related decrease in neural progenitor cell division in the aging brain. Eur J Neurosci 37(12): 1987-1993.

2. Dalgaard JZ (2017) What is the underlying cause of type II diabetes?-Are cells protecting themselves against the reactivity of glucose? Medical Hypotheses 105: 22-24.

3. Li J, Shao YH, Gong YP, Lu YH, Liu Y, et al. (2014) Diabetes mellitus and dementia - a systematic review and metaanalysis. Eur Rev Med Pharmacol Sci 18: 1778-1789.

4. Gow ML, Baur LA, Johnson NA, Cowell CT, Garnett SP (2017) Reversal of type 2 diabetes in youth who adhere to a very-low-energy diet: a pilot study. Diabetologia 60(3): 406-415.

5. Lim EL, Hollingsworth KG, Aribisala BS, Chen MJ, Mathers JC, et al. (2011) Reversal of type 2 diabetes: normalisation of beta cell function in association with decreased pancreas and liver triacylglycerol. Diabetologia 54(10): 2506-2514.

6. Bancher C, Brunner C, Lassmann H, Budka H, Jellinger, KWG, et al. (1989) Accumulation of abnormallyphosphorylated tau precedes the formation ofneurofibrillary tangles in Alzheimer's disease. Brain Res 477(1-2): 90-99.

7. Dalgaard JZ (2017) Could Alzheimer, and related diseases, be due to a cellular repair response gone astray? International Journal of Recent Advances in Multidisciplinary Research 4: 2403-2406.
Your next submission with Juniper Publishers will reach you the below assets

- Quality Editorial service

- Swift Peer Review

- Reprints availability

- E-prints Service

- Manuscript Podcast for convenient understanding

- Global attainment for your research

- Manuscript accessibility in different formats ( Pdf, E-pub, Full Text, Audio)

- Unceasing customer service

Track the below URL for one-step submission https://juniperpublishers.com/online-submission.php 